\title{
Effectiveness of Tempe Biscuits and Honey to Decrease Frequency of Stools in Children Diarrhea
}

\author{
Nurwahidah', Arbianingsih ${ }^{2}$ \\ 1) Nursing Department, Faculty of Medical and Health Sciences, Universitas Islam Negeri Abuddin \\ 2) Pediatric Nursing Department, Faculty of Medical and Health Sciences, Universitas Islam Negeri Alauddin \\ 70300114065@uin-alauddin.ac.id \\ DOI: http://doi.org/10.29080/jhsp.v3i3S.280
}

\section{Keywords}

Children

diarrhea;

Frequency of

stools;

Honey;

Tempe biscuits

\begin{abstract}
Frequency of stools in diarrhea children requires special attention because it can cause dehydration which is the leading cause of death in children with diarrhea. Previous studies state that tempe and honey are effective in reducing the frequency of stools in diarrhea children. However, it is not known which intervention is more effective. Therefore, this study aims to determine whether there is a difference in the effectiveness of tempe biscuits and honey to decrease the frequency of stools in diarrhea. This study employed the quasiexperiment design with two groups pre and post-test. A total of 30 samples were taken by Accidental Sampling. Samples were divided into 2 groups, where 15 people were given the intervention of tempe biscuits, and 15 other people were given honey. Giving tempe biscuits and honey are given 3 times a day for two consecutive days. Data were analyzed using the Wilcoxon Test. The results of this study indicate that tempe biscuits and honey is effective in reducing the frequency of stools in diarrhea children $(p=0.001$ and $p<0,001)$. Although the decrease in the frequency of stools in the group with honey was greater than the group with tempe biscuits, the results of this study showed that there were no significant differences between the two interventions to decrease the frequency of stools ( $p=0.385)$. Therefore, in reducing the frequency of defecation, tempe biscuit and honey can be used as good food supplements for diarrhea children.
\end{abstract}

\section{Introduction}

Diarrhea is a change in the frequency and consistency of stool. WHO in 1984 defined diarrhea as liquid defecation three or more times a day and overnight (24 hours). Mothers may have their own terms such as soft, liquid, bloody, slimy, or vomiting (vomiting). Diarrhea is divided into two based on the time of the (onset), namely acute diarrhea ( $<2$ weeks) and chronic diarrhea ( $>2$ weeks)[1].

Diarrhea is a disease characterized by changes in shape and consistency of softening stool until it melts and the frequency of defecation increases more than usual (three times a day). Diarrhea often attacks infants and toddlers, if not treated immediately it can cause dehydration which causes death[2].

According to the World Health Organization (WHO) and the United Nations Children's Fund (UNICEF), there are 2 billion diarrheal diseases every year and 1.9 million children over 5 years die from diarrheal diseases every year. To the date, it has reached $18 \%$ of all deaths of children under the age of 5 , meaning that more than 5,000 children die every day due to diarrheal diseases[3].

Of all child deaths due to diarrhea, 78\% occurred in Africa and Southeast Asia. Every child under 5 years experiences an average of 3 annual episodes of acute diarrhea globally in this age group, acute diarrhea is the second leading cause of death (after pneumonia), and the risk of death of diarrhea is the most common in children in the age group this, especially during infancy[3].

According to WHO and UNICEF, diarrheal disease is a health problem in the world including Indonesia, currently diarrhea is still the first child killer in Indonesia. Various factors can cause a person to get diarrheal diseases, such as food poisoning, consuming certain fungi, taking medication, stress/ emotions, bacterial infections, and abdominal pain. Diarrhea is liquid stools more than 3 times in 24 hours and focuses more on stool consistency than calculating defecate frequency[4].

The incidence and period prevalence of diarrhea for all age groups in Indonesia are 3.5\% and 7.0\%. The five provinces with the highest incidence and period prevalence of diarrhea were Papua $(6.3 \%$ and 14.7\%), South Sulawesi (5.2\% and 10.2\%), Aceh (5.0\% and 9.3\%), West Sulawesi (4.7\% and 10.1\%) and 
Central Sulawesi (4.4\% and 8.8\%). The incidence of diarrhea in the toddler age group in Indonesia is $10.2 \%[5]$.

According to the Ministry of Health, the government's efforts to overcome diarrhea, especially diarrhea in children under five, have been carried out through various activities such as improving environmental and water sanitation in six regions of the capital city, making communal septic tanks and waste. The expected goals to date have not been achieved and the incidence of diarrhea is still increasing in Indonesia. This is not taken seriously, the government will suffer a lot of losses both in the economic and human resources sectors[6].

According to Cheung \& Chung (2011), other efforts carried out by the Indonesian Ministry of Health and supported by the Indonesian Doctors Association (IDAI) have launched the latest guidelines for the management of diarrhea in children, namely Five Steps to Complete Diarrhea (Cross Diarrhea) which consists of: administration of fluids, giving zinc for 10 consecutive days, continuing breastfeeding and food, giving antibiotics selectively and giving advice to the mother/family of patients[6].

Giving tempeh biscuits to diarrhea patients based on tempeh can shorten the duration of acute diarrhea and accelerate weight gain after suffering from an episode of acute diarrhea. Tempe was chosen as the basic ingredient, because tempe is an easily available traditional food, tempeh contains functional components of probiotics and prebiotics, soluble fiber, polyunsaturated omega 3 fatty acids, conjugation of linoleic acid, antioxidants in plants, vitamins and minerals, some proteins, peptides, and acids amino like phospholipid. According to Toole and Cooney (2008), many microorganisms are considered as prebiotics that are used to maintain traditional food products by fermentation and the presence of these foods are various numbers of microorganisms that are used together with the final results of product and other metabolic fermentation[6].

Tempe is a traditional food that has the potential as a functional food Some of the properties of tempeh for health include hypocholesterolemic effects, antidiarrhea, especially because of enteropathogenic Escherichia Coli and anti-oxidant bacteria. Tempe produced from the fermentation process containing nutrient components in soybeans is digested by molds with enzymatic reactions and simple compounds are produced[7].

Honey has many health benefits, such as antibacterial, antioxidant, and contains many vitamins which are Thiamin, Riboflavin, and Niacin. Honey is even used to facilitate gastrointestinal system disorders, such as constipation, and obesity. Anti-bacterial power of honey is caused by honey containing flavonoids and has an antibacterial mechanism consisting of honey osmosis pressure, acidity, and the presence of inhibine compounds. Honey mainly contains sugar and water. The sugar content contained in honey reaches $95-99 \%$ consisting of fructose $(38,2 \%)$, glucose $(31,3 \%)$ and other types of sugars, such as maltose, sucrose, isomaltose, and some oligosaccharides. In addition, there are also other substances in small amounts, namely amino acids, resins, proteins, salts, and minerals [8].

Some previous studies on the effectiveness of tempeh and honey in decreasing the frequency of defecation in diarrhea toddlers found that tempeh from the results of the study obtained a value of $\mathrm{P}=$ 0,000 , so it can be concluded that there is an effect of giving tempe porridge to the frequency of diarrhea in children. The average value after giving the tempe porridge diet was 2.87 , while the average value after giving the preda pulp diet was 5.40 , so the average difference was -2.53 , so it was proven by giving a more effective tempe porridge diet able lowering the frequency of bowel movements in diarrheal children compared with the provision of preda porridge diet, a study conducted by Setiawati (2005) the effect of giving tempe porridge diet to the frequency of bowel movements in diarrhea children using quasiexperimental methods, where this study showed that tempe had the ability to overcome diarrhea .

Whereas honey in the experimental group was mostly $65 \%$ after being given honey there was a decrease in frequency and level of consistency within 24 hours quickly and in the control group without honey most experienced a decrease in frequency and consistency level within 24 hours slowly (40\%) With a quasy-experimental research design with a post-test only control group. The results of the study based on the Mann-Whitney U-Test test showed that significant value $(0.032 \leq 0.05)$, thus concluded H1 was accepted which means that there was an effect of giving honey on the decrease in the frequency of diarrhea in children under five [9].

Based on preliminary data obtained from the medical record of the Regional General Hospital (RSUD) of Makassar Hajj, the number of cases of diarrhea that went to the hospital from January to December 2016 was 347 cases, from the age of 12 months to 4 years. Based on the existing problems, researchers are interested in comparing the differences in the effectiveness of giving tempe and honey biscuits to reducing the frequency of diarrhea in children under five who are both interventions that can influence the frequency of defecation in children with diarrhea using the quasi-exsperimental design that is two pre and post-test experiment.

\section{Methods}

This study employed analytical research methods, using experimental research designs, namely quasi-experiment with two groups with and post--test namely Thus, the results would be compared of 
interventions from groups treated with different treatment groups.

The population in this study were all children who experienced diarrhea at the time of the study in the Child Care Room of Haji Hospital Makassar.

The independent variable in this study was Tempe Biscuits and Honey. While the dependent variable is the Frequency of Diarrhea, the research tool used was the Reduced Questionnaire: the frequency of diarrhea returned to normal (post test<pre test). The results of the study were analyzed by univariate and bivariate using statistical tests Wilcoxon-Test.

\section{Results}

\section{Characteristics of Respondents}

The following is the frequency distribution of respondents' characteristics based on age and type, medication management and dehydration levels, in the table below:

Table 1. Distribution of Frequency of Respondents Based on Age and Gender in Toddler Children Diarrhea in the Nursing Room of Al-Fajar Haji Hospital Makassar

\begin{tabular}{lccccc}
\hline $\begin{array}{l}\text { Characteristics of } \\
\text { Respondents }\end{array}$ & \multicolumn{2}{c}{ Tempe Biscuit Group } & \multicolumn{2}{c}{ Honey group } & \multirow{2}{*}{ Mann-Whitney } \\
\cline { 2 - 4 } & $\mathbf{F}$ & $\mathbf{\%}$ & $\mathbf{f}$ & $\mathbf{\%}$ & \\
\hline Age & 8 & 53,3 & 5 & 33,3 & \\
2 years & 4 & 26,7 & 6 & 40,0 & 0,339 \\
3 years & 3 & 20.0 & 4 & 26,7 & 0,281 \\
4 years & 15 & 100 & 15 & 100 & \\
\hline Total & 6 & & & 60 & \\
\hline Gender & 9 & 40 & 9 & 40 & 100 \\
Man & 15 & 100 & 15 & 6 & \\
Women & 15 & & & \\
\hline Total & & & & & \\
\hline
\end{tabular}

Table 2. Management of Drug Use in Diarrhea Patients in the Nursing Room of Al-Fajar Child Hospital Haji Makassar Hospital

\begin{tabular}{lllc}
\hline \multicolumn{1}{c}{ Group } & N & Mean & Mann- Whitney \\
\hline Tempe Biscuit & 15 & 15,20 & \\
Honey & 15 & 15,80 & 0,843 \\
\hline Total & 30 & & \\
\hline
\end{tabular}

Table 3. Characteristics of Diarrhea Patients in the Nursing Room of Al-Fajar Children at RSUD Makassar Hajj Based on Respondent's Dehydration

\begin{tabular}{lccc}
\multicolumn{1}{c}{ Group } & N & Mean & Mann- Whitney \\
\hline Tempe Biscuit Group & 15 & 15,50 & \\
Honey Group & 15 & 15,50 & 1,000 \\
\hline Total & 30 & & \\
\hline
\end{tabular}

\section{Univariate Analysis}

Table 4. Distribution of Respondents Based on Observation of Frequency of Pre-Test Chapters and Post-Test for Giving Tempe and Honey Biscuits in Toddler Children with Diarrhea in Al-Fajar Treatment Room at Haji Makassar Hospital

\begin{tabular}{|c|c|c|c|c|c|c|c|c|c|}
\hline \multirow{2}{*}{ Variable } & \multicolumn{2}{|c|}{ 1-3 times a day } & \multicolumn{2}{|c|}{$>3$ times day } & \multicolumn{2}{|c|}{ Jumlah } & \multirow{2}{*}{ Mean } & \multirow{2}{*}{ SD } & \multirow{2}{*}{$p$ value } \\
\hline & $\mathbf{F}$ & $\%$ & f & $\%$ & f & $\%$ & & & \\
\hline Pre-test & & & & & & & & & \\
\hline Tempe Biscuit & 1 & 6,7 & 14 & 93,3 & 15 & 100 & 4,80 & 0,941 & \\
\hline Honey & 1 & 6,7 & 14 & 93,3 & 15 & 100 & 4,87 & 0,990 & 0,845 \\
\hline Post-test & & & & & & & & & \\
\hline Tempe Biscuit & 14 & 93,3 & 1 & 6,7 & 15 & 100 & 2,00 & 0,845 & \\
\hline Honey & 15 & 100 & 0 & 0 & 15 & 100 & 1,73 & 0,799 & 0,385 \\
\hline
\end{tabular}




\section{Bivariate Analysis}

Table 5. Average Value of defecate Frequency Before and After Intervention of Giving Tempe Biscuits and Honey

\begin{tabular}{lcccc}
\hline \multirow{2}{*}{ Group } & \multicolumn{2}{c}{ Average defecation frequency } & Average difference & P-value \\
\cline { 2 - 3 } & Pre-Test & Post-Test & & \\
\hline Tempe Biscuit & 4,80 & 2,00 & 2,8 & 0,001 \\
Honey & 4,87 & 1,73 & 3,14 & 0,000 \\
\hline
\end{tabular}

\section{Discussion \\ Univariate Analysis}

Based on the results of the study, it is shown that the distribution of respondents based on observation of defecation frequency on the first day before administration of tempe with honey biscuits in diarrhea children (pre-test) indicate that the frequency of diarrhea 1-3 times a day both intervention groups tempe biscuits and honey intervention groups respectively as many as 1 person (6.7\%). Meanwhile, the frequency of diarrhea> 3 times a day in both the intervention group of tempe biscuits and the intervention group of honey were 14 people (93.3\%) respectively.

Furthermore, it is also shown that the distribution of respondents based on observation of defecation frequency on the fourth day after administration of tempe with honey biscuits in diarrhea children (posttest) showed that in the intervention group tempe biscuits with BAB frequency 1-3 times a day as many as 14 people ( $93.3 \%$ ), while in the intervention group honey got with defecate frequency 1-3 times a day, which was 15 people (100\%), and frequency of BAB> 3 times a day that is as many as 1 person (6.7\%) for the biscuit intervention group tempe. It can also be seen that after the intervention of tempe and honey biscuits in the honey intervention group, there was a greater decrease in the frequency of diarrhea compared to the intervention group of tempe biscuits.

\section{Bivariate Analysis}

Bivariate analysis was carried out to determine the effect of independent variables (tempe biscuits) and (honey) with the dependent variable (frequency of diarrhea) with the Wilcoxon Test which was indicated by a value of $\mathrm{p}<0.05$. Next, to find out whether the research data was normally distributed to the data before and after being given the intervention of tempe biscuits with honey, the normality test in this study used the Shapiro-Wilk Test. This test was used because the samples studied are less than or equal to 50 Sopiuddin (2009) quoted (in Darmita 2017)[10].

Based on the data normality test, it was found that the data was not normally distributed, so the alternative test used was the Wilcoxon Test.

Based on statistical tests with the Wilcoxon Test in the intervention group, the average tempe biscuit was at pre-test 4.80 and post-test 2.00 . Whereas in the intervention group honey averaged at pre-test 4.87 and post-test 1.73 and p-value of 0.389 . This means that the two groups after being treated the mean defecate frequency had no significant difference ( $\mathrm{p}>0.05)$.

Based on the analysis using the Wilcoxon Test, it was concluded that there was an effect of giving tempe biscuits to the decrease in the frequency of diarrhea in children under five. This is indicated by the significant level of $p=0.001$ smaller than $=0.05$. The results of this study are in line with the research conducted by Sri Yuniatiartiningrum (2010) which aims to determine the differences in the effect of preda and tempe formula on the duration of acute diarrheal disease in children aged $6-24$ months at RA Kartini General Hospital, Jepara Regency. The type of research used was an experimental research design preexperiment with the design of Static group comparison design. The samples were taken accidentally during January-February 2010 as many as 25 with the type of treatment of the preda formula and 25 with tempe. The results showed that the duration of diarrheal disease in the preda formula and tempe was 5 days and 4.2 days, indicating that there was a significant difference in the duration of diarrhea with the type of treatment $(\mathrm{p}=0.010)$.

Diarrhea in infants and toddlers is a big and very complex problem, especially because some sufferers fall into chronic diarrhea or continued diarrhea, and the patient's nutritional condition becomes very bad. This disease was mainly caused by damage to the epithelial cells of the intestinal mucosa tissue. Mucous tissue damage will cause an increase in the absorption of whole proteins, resulting in sensitivity to proteins. There is also a decrease in tissue surface area which has to do the loss loss of disaccharidase activity, resulting in failure of charcoal hydrate absorption. The occurrence of damage to the intestinal mucosa is caused by the entry of causes of infection, including viruses and bacterial enteripatogens[10].

The tempe formula as a nutritional treatment in diarrheal diseases aims to cut the malabsorptionmalnutrition-infection cycle, because the tempeh formula contains high amino acids and is easily digested and easily absorbed and tempeh is antibacterial (Mien, 1987), so that the majority of the causes of 
diarrhea are bacteria (87.5\%), and tempeh proves its ability to cure diarrheal diseases and treatment after diarrhea episodes. These results are in line with the results of Sudigbia (1991). The ability of tempe to cure diarrheal diseases is caused by two things, namely due to anti-diarrhea substances and due to the nature of tempe proteins that are easily absorbed even though the injured intestine (Astawan, 2004) as quoted in Hartaningrum[11].

Rearding with tempe, it is a traditional food with soy-based ingredients through a fermentation process that contains functional components of probiotics and prebiotics, soluble fiber, saturated omega 3 polyun fatty acids, conjugation of linoleic acid, antioxidants and in plants, vitamins and minerals, some proteins, peptides and amino acids, such as phospolipid (Grajek et al, 2005) and according to Toole \& Cooney (2008), many microorganim which are considered as probiotics are used to maintain traditional food products by fermentation and the presence of these foods various numbers of microorganisms used together with the final results of fermentation other products and metabolism Toole \& Cooney cited in Hartaningrum[11].

Diarrhea problems in infants and toddlers are important to give an attention especially in damage to the intestinal mucosa and limitations of digestive enzymes. In addition to treatment to repair tissue damage, managing is an important part of managing diarrhea problems in infants and toddlers. The aim of managing is to provide nutrients in the right amount and composition, at least to fulfill metabolic survival, and it will be better if it can improve the growth and development of patients. A problem that is always questioned, what foods should be given to infants, and children with diarrhea. Tempe formula food has been studied for its effects on physical development, the chance of diarrhea, and the risk of diarrhea due to bacterial enteropathogen infection.

The treatment process for children with chronic diarrhea, then giving baby food tempe formula, is more effective than milk formula baby food This happens because the protein in most tempeh has been hydrolyzed during the fermentation process of soybeans, becoming free amino acids.

Although in patients with diarrhea, there is damage to the intestinal mucous tissue, the protein in tempe will not be absorbed in the form of whole proteins, so it will not cause sensitivity to proteins. Because protein has decomposed into amino acids, even though patients lack proteolytic enzymes, the protein will not disappear, because amino acids can be directly absorbed and utilized by the body for growth.

It is known that during the fermentation process of soybeans into tempeh, fat is hydrolyzed into free fatty acids which are ready to be absorbed. Although patients with lipase enzymes are deficient, fats in the tempe formula food will be absorbed. During fermentation, Rhizopus molds produce lipases with very high activity (Mahmud K, 1987) quoted in[10].

In the research process on the 2 nd and 3rd day, the intervention group was given MP ASI 3 times a day, so that each respondent received 6 times the tempe formula during the study. Based on the SOP of this study, that every time giving tempe formula is as much as 50 grams. The information reported in Fatseret Indonesia (2017) that in every 50 grams of tempeh contains 58\% carbohydrates and the rest is protein and calories as much as $113 \mathrm{kcal}$. Therefore, by giving MP ASI, this is enough to encourage children energized and it appears that children are not too weak compared during the observation period on the first day of the study[10].

In this study, measurements were carried out using the Wilcoxon Test to measure the BAB frequency pre-post test in the tempe biscuit group. From the results of the Wilcoxon Test test obtained a value of $p=$ $0.001<=0.05$, it can be concluded that there is a change in the decrease in frequency of defecation after the intervention of giving biscuits. These results are significant giving tempe biscuits given to respondents can reduce the frequency of bowel movements. This shows that non-pharmacological therapy with tempe biscuits has been able to change the frequency of defecate toddlers with diarrhea in the Al-Fajar Room at Haji Hospital Makassar.

Based on the analysis using the Wilcoxon Test, it was concluded that there was an effect of honey drinks on the decrease in the frequency of diarrhea in children under five. This is indicated by a significance level of $\mathrm{p}=0,000$ smaller than $=0,05$.

\section{Osmolarity}

Based on the mechanism of action on honey, namely:

Some studies have found that honey has an antimicrobial effect. This antimicrobial effect is due to osmolarity, the content of hydrogen peroxide and other ingredients. The low water content in honey which amounts to 0.52-0.62 which inhibits the growth of large bacteria and some types of yeast and fungi. When honey is given topically to the wound, the osmosis in honey absorbs water from the wound so that it can help drain infected tissue and reduce bacterial growth. Staphylococcus aureus is one of the bacteria that is resistant to low water activity. In an observation it was found that this bacterium can still grow in water activities of 0.86 . These bacteria can still grow in infected skin which is treated with concentrates of pure sugar solution, but these bacteria are sensitive to other antimicrobial components contained in honey with the same amount of water activity. Antimicrobial activity in honey is not only due to low water activity, many studies have compared sugar syrup with water activity similar to honey and it was found that sugar 
syrup was less effective in inhibiting microbial growth in viro compared to honey[12].

\section{The level of equality}

Based on several studies, honey has a slightly lower $\mathrm{pH}$, which is from 3.2 to 4.5 . Gluconic acid in honey is formed by the enzyme glucose oxidase which is secreted by bees. The enzyme catalyzes the oxidation process of glucose into gluconic acid. Low $\mathrm{pH}$ itself has been able to inhibit the growth of various pathogenic bacteria, especially in topical use. On oral administration, the effect of a low pH in honey will be lost due to changes in acidity in the stomach and intestinal lumen[12].

\section{Hydrogen peroxide}

Research conducted by White, Hubers \& Schepartz identified hydrogen peroxide as a source of major antimicrobial activity in honey. In addition to producing gluconic acid, the breakdown of glucose by the glucose oxidase enzyme also produces hydrogen peroxide. The activity of glucose oxidase will increase if honey is dissolved in water.

Here is the formula for the formation of hydrogen peroxide.

Glucose $+\mathrm{H} 20+02 \rightarrow$ glucosidase $\rightarrow$ Gluconic Acid $\rightarrow \mathrm{H} 20$

Hydrogen peroxide produced from the results of the above reaction will be very low around 1-2 $\mathrm{mmol} /$ liter of honey. While use in the medical field the concentration of hydrogen peroxide is around $3 \%$ by weight per volume. If honey is not dissolved in water, the resulting gluconic acid will reduce the $\mathrm{pH}$ to the point where enzyme activity will be inhibited, so that subsequent production of hydrogen peroxide is also inhibited. If excessive heat can also reduce glucose oxidase activity[12].

This is in line with the results of experiments conducted by a researcher from New Zealand to conduct experiments on the ability of honey to overcome bacteria that cause injury and bleeding in digestion, and about the ability of beneficial bacteria to disinfect. They found that the high sugar content in honey can slow the development of bacteria. When applied, honey has a high ability to overcome the problem of external infections. In addition, honey can also kill bacteria that cannot be killed by ordinary antibiotics (Asy-Syahawi, 2011) in the bank in Nurazizah[13].

One expert has carried out scientific experiments on honey. He takes bacteria from various diseases and puts them in honey. The result he got was honey has an ability to kill thyphoid bacillus within 48 hours. It can also kill parathypoid bacilli (paratifus) within 24 hours. On the fourth day, bacteria that cause lung infections can be destroyed. While the bacteria that cause dysentery can be overcome within 10 hours (AsySyahawi, 2011) in the school in Nurazizah[13].

The results of this study agrees with the research conducted by Purnawati et al (2016) which aims to identify the effectiveness of honey therapy to reduce the frequency of diarrhea and bowel sounds in children under five years of age. This type of research used quasi-experimental design with nonequivalent control group types before after design. The number of samples 46 was divided into two groups, namely the control and intervention groups. The results of this study indicate a group $(p=0,000 ; \breve{\alpha}=0,05)$. It can be concluded that the administration of honey is a significant difference in the frequency of diarrhea and bowel sounds in both effective ways to reduce the frequency of diarrhea and bowel sounds.

Most acute diarrhea is caused by infection. Many of the effects that occur due to gastrointestinal infections include: removing toxins that can cause disruption of secretion and reabsorption of fluids and electrolytes with the result of dehydration, electrolyte balance disorders and disorders of acid-base balance. Invasion and destruction of epithelial cels, penetration into the lamina propia and damage to microvilli which can cause maldigesti and malabsorption conditions and if they do not get adequate treatment. Brunner (quoted in Nurazizah, 2015)[13.

Some cases have been found to spread pathogens due to contaminated food and drink. The basic mechanism that causes diarrhea is an osmotic disorder (food that cannot be absorbed will cause osmotic pressure in the intestinal cavity to increase so that there is a shift in water and electrolytes into the intestinal cavity, excessive intestinal cavity and diarrhea) Brunner (2011 quoted in Nurazizah, 2015)[13].

One of the risk factors for diarrhea is the age-susceptible children, especially at the age of five, this can be caused because in toddlers the children will easily eat food contaminated by pathogenic microorganisms that cause diarrhea.

According to Asritadda (2010), enteral infection is an infection of the digestive tract which is the main cause of diarrhea in children, this includes bacterial infections (E. coli, Salmonella, Vibrio cholera), viruses (enterovirus, adenovirus, rotavirus), parasites (worms,protozoa). Parenteral infections are infections originating from other parts of the body outside the digestive tract, such as acute otitis media (OMA), tonsillofaringitis, bronchopneumonia.

There are some medical experts who say: "In the human stomach there are many deposits of food scraps, and after being given honey, which is indeed hot honey, the sediment is released and immediately pushed out so that it makes his stomach get sick. So the Badui thought that honey would only harm him, even though he was very beneficial to his brother. Then he gave him a drink for the second time and the pain increased and the honey pushed harder the dirt deposits. Then, he gave him a drink for the third time. 
When honey pushes the remaining food that has been damaged and is harmful to the body, the stomach persists and the pressure becomes normal so that all diseases are pushed out thanks to the instructions of the Prophet who received revelation from his Lord Abdullah (quoted in Nurazizah 2015: 79)[13].

In this study, measurements were carried out using the Wilcoxon Test to measure BAB frequency pre-post test in the honey group. From the results of the Wilcoxon Test test obtained a value of $p=0,000<=$ 0,05 , it can be concluded that there is a change in the decrease in frequency of BAB after the intervention of honey administration. These results mean that the honey drink given to respondents was able to reduce the frequency of bowel movements. This shows that non-pharmacological therapy with honey has been able to change the frequency of BAB children with diarrhea in the Al-Fajar Room at Haji Hospital Makassar.

The difference between the two interventions was to decrease the frequency of bowel movements.

Based on the analysis using the Wilcoxon Test, the p-value in the honey group was smaller than the tempe biscuit group $(0.000<0.001)$. This shows that the honey group given the intervention was more effective on the frequency of defecation than the tempe biscuit group.

These results are significant that by giving tempe biscuits and honey drinks which are given to respondents can reduce the frequency of bowel movements. This shows that non-pharmacological therapy with tempe biscuits with honey has been able to change the frequency of defecate toddlers with diarrhea in the Al-Fajar Room at Haji Hospital Makassar.

\section{Conclusion and Suggestion}

Based on the results of the research before being given tempe biscuit intervention, most BAB frequencies were $>3$ times a day as many as 15 people, whereas before being given the intervention of honey, most of the frequency of defecation was $>3$ times a day which was 15 people. Based on the results of the research after being given the intervention of biscuits, the frequency of defecation to $1-3 \mathrm{x}$ a day is equal to 15 people, while the results of the research after being given intervention in honey the BAB frequency is $1-3 \mathrm{x}$ a day which is 15 people. Based on the results of the study it was found that there was a difference between the intervention group of tempe biscuits and the intervention group honey on the frequency of bowel with a value of $p=<0.05$. Based on the results of the study, there is a difference in the effectiveness of giving tempe and honey biscuits to the reduction in frequency of bowel movements in children with diarrhea after treatment in the Al-Fajar Nursing Room at Haji Hospital Makassar.

\section{References}

1. Widoyono. Tropical Epidemiology, Transmission, Prevention \& Eradication. Jakarta: Erlangga. 2011

2. Nurfita, D. Factors Related to Diarrhea in Toddlers at Bulu Lor Health Center, Semarang City. KesMas: Faculty of Public Health Journal, 11 (2), 153-158. 2017

3. Farthing, M., Salam, M. A., Lindberg, G., Dite, P., Khalif, I., Salazar-Lindo, E., Khan, A. G. Acute diarrhea in adults and children: a global perspective. Journal Clin Gastroenterol, 47 (1), 12-20. https://doi.org/10.1097/MCG.0b013e31826df662. 2013

4. Health Office. Makassar City Health Profile 2015, 45. 2016.

5. RI Ministry of Health. Basic Health Research (RISKESDAS) 2013. 2013 National Report, 1-384. https://doi.org/1 December 2013. 2013

6. Setiawati, H. Effect of Giving Tempe Porridge Diet on CHAPTER Frequency in Diarrhea Children in the Mina Room of PKU Muhammadiyah Hospital in Surakarta. Scientific Publication Script. 2015

7. Cahyadi. Soybean Benefits and Technology. Jakarta: Bumi Aksara. 2012

8. Nadhilla, N. F. (2014). The Activity Of Antibacterial Agent Of Honey Against Staphylococcus aureus at the University of Waikato in New Zealand. Review Articles, 3, 94-101. 2014

9. Puspitayani, D., \& Fatimah, L. Effect of Giving Honey on Decreasing the Frequency of Diarrhea in Toddlers in Ngumpul Village, Jogoroto, Jombang. Eduhealth Journal, 4 (2), 2-7. 2014

10. Darmita. Effect of Provision of Complementary Food ASI (MP-ASI) Tempe Formula Against CHAPTER Frequency in Children Diarrhea Ages 6-24 Months in Syekh Yusuf District Hospital. Gowa. Thesis of Makassar Alauddin State University. 2017

11. Hartiningrum, S. Y. Effect of Giving Preda and Tempe Formulas on the Duration of Acute Diarrhea in Children Aged 6-24 Months. Thesis. Diponegoro University Semarang. 2010

12. Cholid, S., Santosa, B., \& Suhartono. Effects of Honey on Acute Diarrhea. Pediatric Spokes, 12 (5), 289295. Retrieved from http://saripediatri.idai.or.id/pdfile/12-5-1.pdf. 2011

13. Nurazizah. Effectiveness of Giving Honey on the Frequency of Defecation (Chapter) and BodyWeight in Acute Gastroenteritis (Gea) Patients in the Baji Minasa Room of Rsud Labuang Baji Makassar in 2015, Thesis of Alauddin Makassar Islamic University. 1-83. 2015 